NASA Technical Memorandum 83706

\title{
Sputtered Coatings for Protection of Spacecraft Polymers
}

Bruce A. Banks, Michael J. Mirtich, Sharon K. Rutledge, and Diane M. Swec

Lewis Research Center

Cleveland, Ohio

Prepared for the

Eleventh International Conference on Metallurgical Coatings sponsored by the American Vacuum Society

San Diego, California, April 9-13, 1984

\section{N/SN}




\section{SPUTTERED COATINGS FOR PROTECTION OF SPACECRAFT POLYMERS}

Bruce A. Banks, Michael J. Mirtich, Sharon K. Rutledge and Diane M. Swec National Aeronautics and Space Administration

Lewis Research Center

Cleveland, Ohio 44135

\section{SUMMARY}

Kapton polyimide oxidizes at significant rates $\left(4.3 \times 10^{-24}\right.$ gram/incident oxygen atom) when exposed in low earth orbit to the ram atomic oxygen flux. Ion beam sputter deposited thin films of $\mathrm{Al}_{2} \mathrm{O}_{3}$ and $\mathrm{SiO}_{2}$ as well as a codeposited mixture of predominantly $\mathrm{SiO}_{2}$ with a small amount of polytetrafluoroethylene were evaluated and found to be effective in protecting Kapton from oxidation in both laboratory plasma ashing tests as well as in space on board Shuttle flight STS-8. A protective film of $\geq 96$ percent $\mathrm{SiO}_{2}$ and $\leq 4$ percent polytetrafluoroethylene was found to be very flexible compared to the pure metal-oxide coatings and resulted in mass loss rates that were 0.2 percent of that of the unprotected Kapton®. The optical properties of Kapton for wavelengths investigated between 0.33 and $2.2 \mu \mathrm{m}$ were not significantly altered by the presence of the coatings or changed by exposure of the coated Kapton to the low earth orbital ram environment.

\section{INTRODUCTION}

Early Shuttle flights have demonstrated that materials such as polyimide (Kapton®), carbon coatings, and some paints undergo wejght loss and changes in optical properties when exposed in low earth orbit. 1 The postulated mechanism for these material changes is oxidation by atomic oxygen atoms which energetically ( $5 \mathrm{eV})$ impact into the exposed spacecraft surfaces because of the spacecrafts orbital ram velocity relative to the geostationary low-earthorbital environment which is predominantly atomic oxygen at altitudes between $180 \mathrm{~km}(97 \mathrm{n} \mathrm{mi})$ and $650 \mathrm{~km}$ (351 $\mathrm{n} \mathrm{mi}) .2$ Materials which form volatile oxides when exposed to ram atomic oxygen typically become mat in appearance due to microscopic surface fibrils or cone like structures which are a result of oxidation by the directed atomic oxygen flux. ${ }^{3}$ The observed rates of oxidation of Kapton and Mylar are sufficiently high as to cause concern for their survival as solar cell blankets or thermal blankets when used in low earth orbital applications of any significant duration. 4 Thus considerable interest exists in identifying oxidation resistant substitute polymeric materials or protective coatings suitable to prevent oxidation on existing polymers such as Kapton and Mylarø.

This paper presents an approach which utilizes thin films of predominantly metal oxide coatings as a means of preventing oxidation of polymers. Thus the protection of the polymer surface from oxidation is afforded by nonvolatile metal oxides which are already in their highest oxidation state. Because metal oxides such as $\mathrm{SiO}_{2}$ and $\mathrm{Al}_{2} \mathrm{O}_{3}$ are brittle a molecularly mixed film of predominantly metal oxide with a little fluoropolymer was thought to be an attractive approach to gain both oxidation protection from the oxide component and perhaps added flexibility as a result of the polymeric constituent. 
APPARATUS AND PROCEDURE

\section{Coating Deposition and Selection}

Two types of thin film coatings were investigated for oxidation protection for Kapton polyimide. These were pure metal oxides and a molecular mixture of metal oxide and fluoropolymer. The thin films were deposited by ion beam sputter deposition after 2 minutes of ion beam sputter cleaning the Kapton substrates as shown in figure 1 . An $8 \mathrm{~cm}$ diameter ion source was used to produce a $1000 \mathrm{eV}, 65 \mathrm{~mA}$ argon ion beam for sputter cleaning and deposition. 5 A ion beam current density of up to $\sim 2.8 \mathrm{~mA} / \mathrm{cm}^{2}$ resulted in the vicinity of the sputter target and Kapton substrates which were located approximately $20 \mathrm{~cm}$ downstream of the ion source. The ion source was operated with a hot wire neutralizer in a vacuum facility $4.5 \mathrm{~m}$ long by $1.5 \mathrm{~m}$ in diameter which maintained pressures of $3 \times 10^{-5}$ torr during ion source operation. Smooth fused silica slides were also mounted with the Kapton ${ }^{\circ}$ substrates to allow documentation of film thickness. Deposited film thickneses were measured by means of a surface profiling instrument (Alpha-Step Profiler ${ }^{\otimes}$, Tencor Instruments) by tracing the surface with a stylus passing from a virgin portion of the fused silica surface (which was protected by means of a polyimide tape) to the deposited surface. Sputter targets were $15.24 \mathrm{~cm}$ diameter disks of $\mathrm{SiO}_{2}$ or $\mathrm{Al}_{2} \mathrm{O}_{3}$ for deposition of single constituent metal oxide films, and $\mathrm{SiO}_{2}$ with polytetrafluoroethylene (Teflon®) bars or tubes ranging from 19.1 to $0.44 \mathrm{~mm}$ wide stretched across the diameter of the $\mathrm{SiO}_{2}$ target for the codeposited films.

Because solar array and thermal blankets of Kapton may require such oxidation protective coatings, the flexibility of the coated blanket is a pertinent consideration. The deposited thin film coatings on $0.127 \mathrm{~mm}$ Kapton $ه$ were subjected to compressive and tensile stresses by wrapping the coated Kaptono (with the coated surface concave then convex) around various size mandrels ranging in radif from 10.16 to $0.008 \mathrm{~cm}$. The coated surfaces were then microscopically examined for crazing and/or spalling.

The oxidation protection capability of various thickness and composition coatings were evaluated with an RF plasma asher (SPI Plasma Prep IIه) to produce atomic oxygen bombardment of samples. Both coated and uncoated Kapton samples were subjected to low pressure RF air discharge for approxi-mately 15 hours during which typically 18 percent of the unprotected Kapton's $0.127 \mathrm{~mm}$ total thickness would be removed by oxidation. Samples were protected by glass slides such that only one surface (the coated surface for the protected samples) was exposed to the RF plasma. Samples were evaluated to compare weight loss after allowing sufficient time for reabsorption of moisture.

Thin film coating composition and thickness selected for space flight testing were based on the results of the flexibility tests and plasma asher tests.

\section{Space Experiment}

Circular $2.54 \mathrm{~cm}$ diameter $0.127 \mathrm{~mm}$ thick unprotected and three thin $\mathrm{film}$ protected Kapton ${ }^{\circledR}$ samples were mounted in aluminum trays which allowed space exposure of a $2.06 \mathrm{~cm}$ diameter central portion of each sample. The unprotected 
sample of Kapton was a control for the coated samples as well as others not described in this paper and had an aluminum film deposited on its unexposed surface. The control sample aluminum film as well as the protective coatings were all deposited on the smoothest side of the Kapton substrates. The samples as mounted in their flight tray are shown figure 2. This tray was located within the shuttle bay of STS- 8 as shown in figure 3 . This allowed normally incident ram atomic oxygen flux to impinge upon the samples.

Samples were docummented by optical microscopic photography, scanning electron microscopy (Amray 1400), energy dispersive spectroscopy (Kevex EDS system), mass change, optical reflectance, absorptance and transmittance (by means of a Gier-Dunck $1 e^{\circledR}$ integrating sphere in conjunction with a tungsten strip lamp and monochrometer) to allow an evaluation of the characteristics and effectiveness of the thin film protective coatings.

\section{RESULTS AND DISCUSSION}

\section{Coating Selection for Space Flight Test}

Thin film coatings selected for space flight testing were $700 \AA$ of $\mathrm{Al}_{2} \mathrm{O}_{3}$, $650 \AA$ of $\mathrm{SiO}_{2}$, and $650 \AA$ of $\geq 96$ percent $\mathrm{SiO}_{2}$ with $\leq 4$ percent (by volume) polytetrafluoroethylene (PTFE). The codeposition target for the $\geq 96$ percent $\mathrm{SiO}_{2}$ $\leq 4$ percent PTFE film utilized a $0.44 \mathrm{~mm}$ PTFE tube stretched across the $\mathrm{SiO}_{2}$ target as the source of the $\leq 4$ percent PTFE in the codeposited $f 11 \mathrm{~m}$. Film thickneses evaluated ranged from $400 \AA$ to $1000 \AA$. The minimum radius of curvature that each selected coating could survive on $0.127 \mathrm{~mm}$ thick Kapton ${ }^{\infty}$ without crazing or spalling was found to be $6.35 \mathrm{~mm}$ for $700 \AA$ of $\mathrm{Al}_{2} \mathrm{O}_{3}$, $3.18 \mathrm{~mm}$ for $650 \AA$ of $\mathrm{SiO}_{2}$, and near zero for $650 \AA$ of $\geq 96$ percent $\mathrm{SiO}_{2} \leq 4$ percent PTFE. The codeposited film showed no evidence of failure even with a $180^{\circ}$ fold back of the Kapton on itself. Codeposited films with a significant fractional fluoropolymer content such as 65 percent $\mathrm{SiO}_{2} 35$ percent PTFE were found to be ineffective in protecting the Kapton in the plasma ashing tests.

\section{Space Flight Test Results}

The samples were exposed to the ram atomic oxygen environment of $222 \mathrm{~km}$ (120 $\mathrm{n} \mathrm{mi}$ ) during Shuttle Flight 8 in three separate exposure periods on September 3,4, and 5, 1983 for a total of 41.17 hours. This was accomplished by orbiting the earth with the shuttle bay doors open to allow the sample trays to ram with normal incidence into the environmental atmosphere.

The unprotected Kapton sample developed a mat surface (or increase in diffuse reflectance) as a result of the space exposure whereas no significant change beyond the experimental measurement error was found to occur in the $\mathrm{Al}_{2} \mathrm{O}_{3}, \mathrm{SiO}_{2}$, or $\geq 96$ percent $\mathrm{SiO}_{2}, \leq 4$ percent PTFE samples. Figure 4 an 5 compare the changes in optical properties of unprotected and $\geq 96$ percent $\mathrm{SiO}_{2}$, $\leq 4$ percent PTFE protected Kapton. The transmittance is not shown in figure 4 because its value is zero for the wavelength region shown due to the aluminum coating on the unexposed surface. The optical properties of reflectance, absorptance, and transmittance for $\mathrm{Al}_{2} \mathrm{O}_{3}$ and $\mathrm{SiO}_{2}$ are not presented in this paper because they were indistinguishable from each other and the $\geq 96$ percent $\mathrm{SiO}_{2} \leq 4$ percent PTFE sample. From Figs. 4 and 5 one can conclude 
that the thin film coatings of $\mathrm{Al}_{2} \mathrm{O}_{3}, \mathrm{SiO}_{2}$, and $\geq 96$ percent $\mathrm{SiO}_{2} \leq 4$

percent PTFE do not significantiy (over the wavelength region of $0.33-2.2 \mu \mathrm{m}$ ) alter the optical properties of uncoated Kapton ${ }^{\circledR}$ and upon exposure to the low earth orbital environment also did not change as does the unprotected Kapton.

Table I compares the mass losses of the protected and unprotected Kapton samples that resulted from the exposure to the low earth orbital environment.

The unprotected Kapton® was found to lose an equivalent thickness of $2.6 \times 10^{-4} \mathrm{~mm} / \mathrm{hr}\left(7 \times 10^{-5} \mathrm{in.} / \mathrm{hr}\right)$ while being exposed to the ram atomic oxygen flux. This rate was found to be consistant with several other investigators also onboard STS-8. The rate of mass loss of the $\mathrm{Al}_{2} \mathrm{O}_{3}$ coated sample would indicate that six times the mass of the protective coating was removed. However energy dispersive spectroscopy substantiated the presence of the coating. Even though the mass loss of the $\mathrm{Al}_{2} \mathrm{O}_{3}$ protected Kapton was only 11 percent of that of the unprotected, there is a significant probability that a missing Kapton shard (lost during sample mounting or removal) contributed to this mass 10ss. Thus the $\mathrm{Al}_{2} \mathrm{O}_{3}$ coatings actual performance is probably more similar to the $\mathrm{SiO}_{2}$ coating which lost only 0.1 percent of the mass of unprotected Kapton. One can aiso see that the more flexible $>96$ percent $\mathrm{SiO}_{2} \leq 4$ percent PTFE coating was also very effective in protection of the polyimide with only 0.2 percent of the unprotected loss rate. Energy dispersive $X$-ray spectrometry (EDS) also confirmed the presence of both the $\mathrm{SiO}_{2}$ and $\geq 96$ percent $\mathrm{SiO}_{2} \leq 4$ percent PTFE coatings. Scanning electron microscopy also gave strong support that the atomic oxygen which significantly textured the unprotected Kapton did not alter any of the three coated Kapton® surfaces. Figure 5 compares scanning electron microscope photographs of the unprotected and $\geq 96$ percent $\mathrm{SiO}_{2} \leq 4$ percent PTFE protected Kapton samples before and after space flight exposure. As can be seen significant surface texturing of the unprotected Kapton occurs. The textured surface abviousiy is the predominant cause of the mat appearance of the post flight unprotected Kaptonه. All of the three protective coatings yielded the same results upon scanning electron microscope inspection. That is, the thin film coatings showed now significant alteration in surface morphology upon deposition on the Kapton or change as a result of exposure in low earth orbit.

\section{CONCLUSIONS}

Ion beam sputter deposited thin film of $700 \AA$ of $\mathrm{Al}_{2} \mathrm{O}_{3}, 650 \AA$ of $\mathrm{SiO}_{2}$, and $\geq 96$ percent $\mathrm{SiO}_{2} \leq 4$ percent PTFE were found to be effective in prevent ing oxidation of Kapton exposed to ram atomic oxygen in low earth orbit. The codeposited $f 11 \mathrm{~m}$ of $\geq 96$ percent $\mathrm{SiO}_{2} \leq 4$ percent PTFE was found to be more flexible than the either of the pure meta the codeposited $f 11 \mathrm{~m}$ and exposed for $41.17 \mathrm{hr}$ to the orbital ram environment at $222 \mathrm{~km}$ ( $120 \mathrm{n} \mathrm{mi})$ resulted in mass loss rates of 0.2 percent of that of the unprotected Kapton $\otimes$. The optical properties of reflectance, absorptance, and transmittance over the wavelengths of 0.33 to $2.2 \mu \mathrm{m}$ were not significantly altered by the presence of the films, and furthermore, did not change upon exposure of the thin-film-coated Kapton to the low earth orbital ram environment. 


\section{ACKNOWLEDGMENTS}

The authors gratefully acknowledge the efforts of Dale Ferguson, Bob Roman, Ralph Jacko, and David Bates who significantly contributed to this investigation.

\section{REFERENCES}

1. L. J. Leger, Oxygen Atom Reaction with Shuttle Materials at Orbital Altitudes, NASA Tech. Memo. TM-58246, 1982.

2. NOAA, NASA, and USAF, U.S. Standard Atmosphere, 1976, NASA Tech. Memo. Tm $X-74335,1976$.

3. D. C. Ferguson, Laboratory Degradation of Kapton in a Low Energy 0xygen Ion Beam, NASA Tech. Memo. TM-83530, 1984.

4. A. F. Whitaker, LEO Atomic Effects on Spacecraft Materials, Paper presented at the AIAA Shuttle Environment and Operations Meeting, Washington D.C., OCt. 31 to Nov. 2, 1983, AIAA-83-2632-CP.

5. B. A. Banks and S. K. Rutledge, Ion Beam Sputter Deposited Diamondlike Films, NASA Tech. Memo. TM-82873, 1982.

TABLE I. - MASS LOSS OF PROTECTED AND UNPROTECTED KAPTONO SAMPLES TO LOW EARTH ORBITAL ENVIRONMENT

\begin{tabular}{|l|c|c|c|}
\hline $\begin{array}{c}\text { Protective coating } \\
\text { on Kaptone }\end{array}$ & $\begin{array}{c}\text { Thickness of } \\
\text { protective } \\
\text { coating, } \AA\end{array}$ & $\begin{array}{c}\text { Mass } \\
\text { loss, } \mu \mathrm{g}\end{array}$ & $\begin{array}{c}\text { Mass loss per } \\
\text { incident oxygen } \\
\text { atom*, g/atom }\end{array}$ \\
\hline None (Unprotected) & 0 & $5020 \pm 9.9$ & $4.3 \times 10^{-24}$ \\
$\mathrm{Al}_{2} \mathrm{O}_{3}$ & 700 & $567 \pm 5.2$ & $4.8 \times 10^{-25}$ \\
$\mathrm{SiO}_{2}$ & 650 & $5.9 \pm 5.2$ & $5.0 \times 10^{-27}$ \\
$\geq 96 \% \mathrm{SiO}_{2} \leq 4 \%$ PTFE & 650 & $10.3 \pm 5.2$ & $8.8 \times 10^{-27}$ \\
\hline
\end{tabular}

*Based on an estimated atomic oxygen fluence of $3.5 \times 10^{20}$ atoms $/ \mathrm{cm}^{2}$ 
TABLE I. - MASS LOSS OF PROTECTED AND UNPROTECTED KAPTON囚 SAMPLES TO LOW EARTH ORBITAL ENVIRONMENT

\begin{tabular}{|c|c|c|c|}
\hline $\begin{array}{c}\text { Protective coating } \\
\text { on Kapton }\end{array}$ & $\begin{array}{c}\text { Thickness of } \\
\text { protective } \\
\text { coating, }\end{array}$ & $\begin{array}{c}\text { Mass } \\
\text { loss, } \mu \mathrm{g}\end{array}$ & $\begin{array}{c}\text { Mass loss per } \\
\text { incident oxygen } \\
\text { atom*, g/atom }\end{array}$ \\
\hline None (Unprotected) & 0 & $5020 \pm 9.9$ & $4.3 \times 10^{-24}$ \\
$\mathrm{Al}_{2} \mathrm{O}_{3}$ & 700 & $567 \pm 5.2$ & $4.8 \times 10^{-25}$ \\
$\mathrm{SiO}_{2} \mathrm{SiO}_{2} \leq 4 \%$ PTFE & 650 & $5.9 \pm 5.2$ & $5.0 \times 10^{-27}$ \\
$\geq 96 \% \mathrm{Si}_{2}$ & 650 & $10.3 \pm 5.2$ & $8.8 \times 10^{-27}$ \\
\hline
\end{tabular}

*Based on an estimated atomic oxygen fluence of $3.5 \times 10^{20}$ atoms $/ \mathrm{cm}^{2}$. 


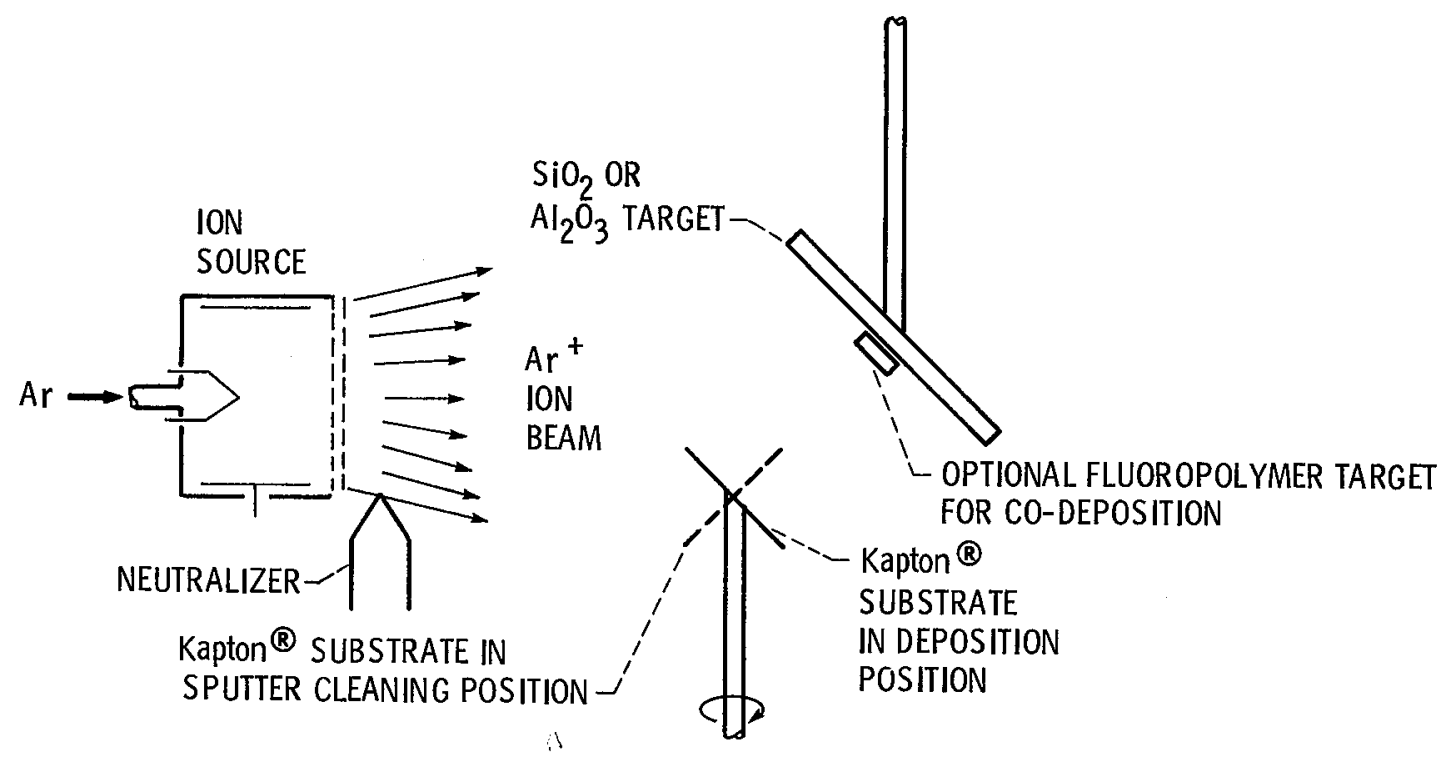

Figure 1. - Ion beam sputter cleaning and deposition configuration.

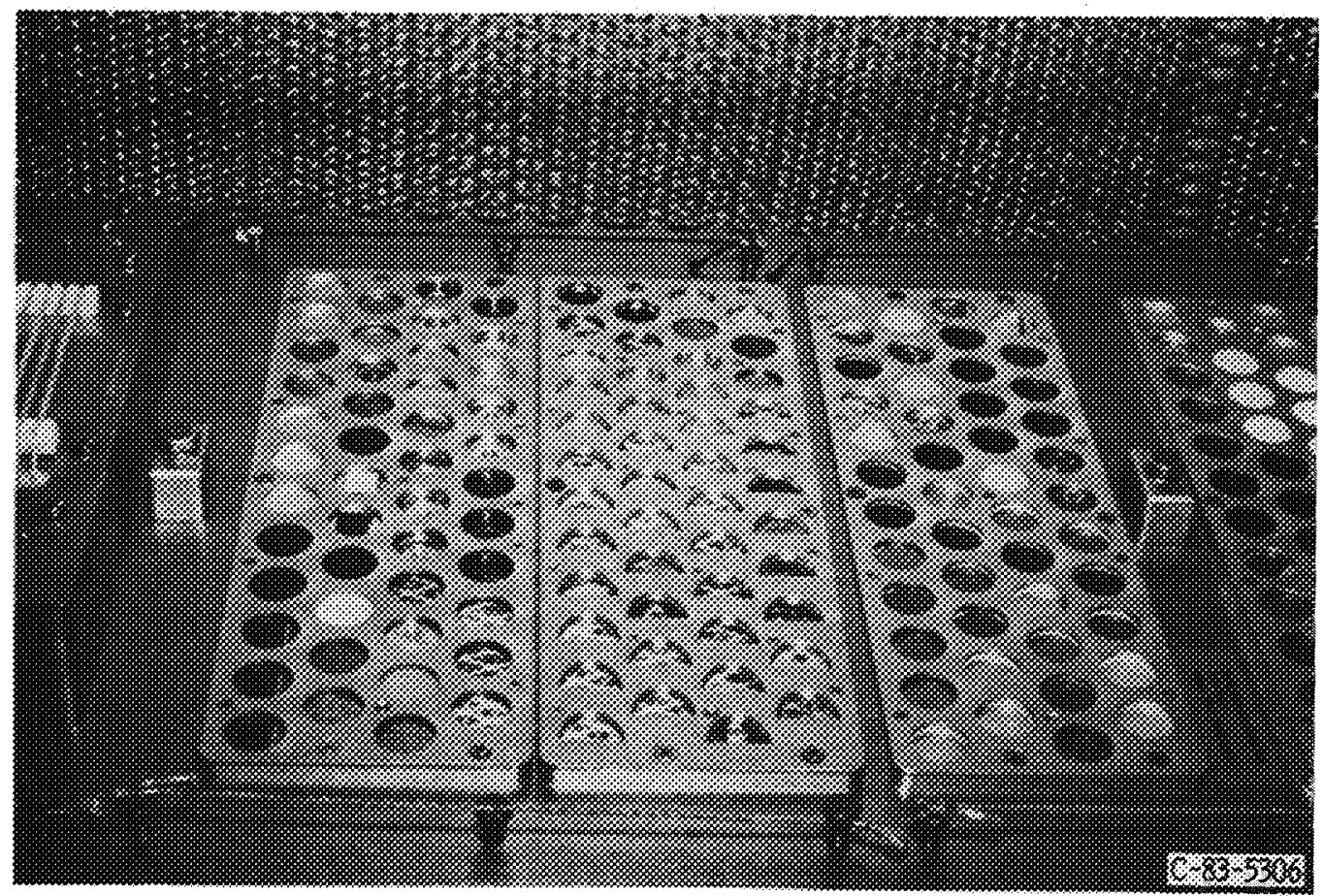

Figure 2. - Shuttle experiment sample tray. 


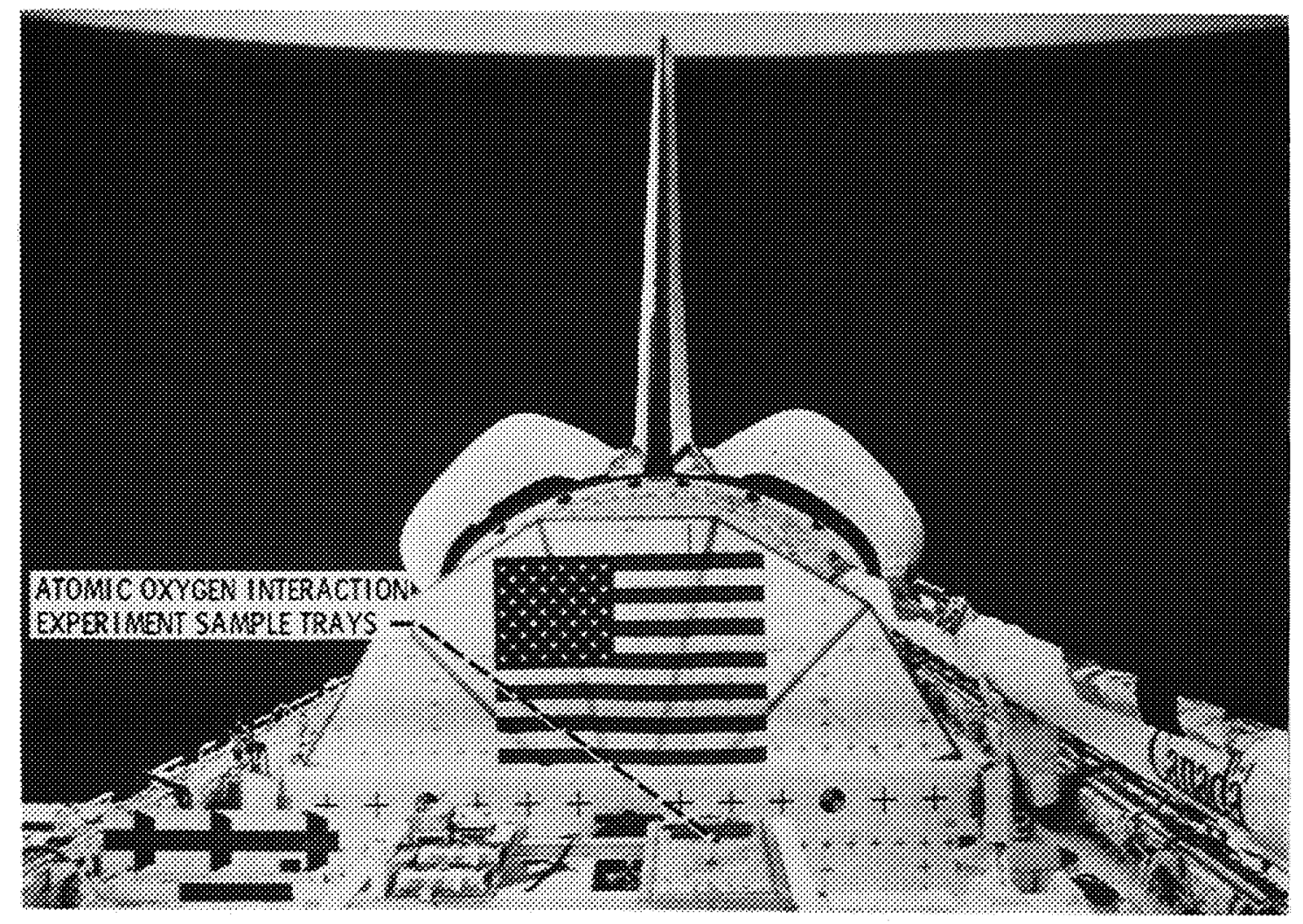

Figure 3. - Shuttle experiment in the bay of STS-8. 

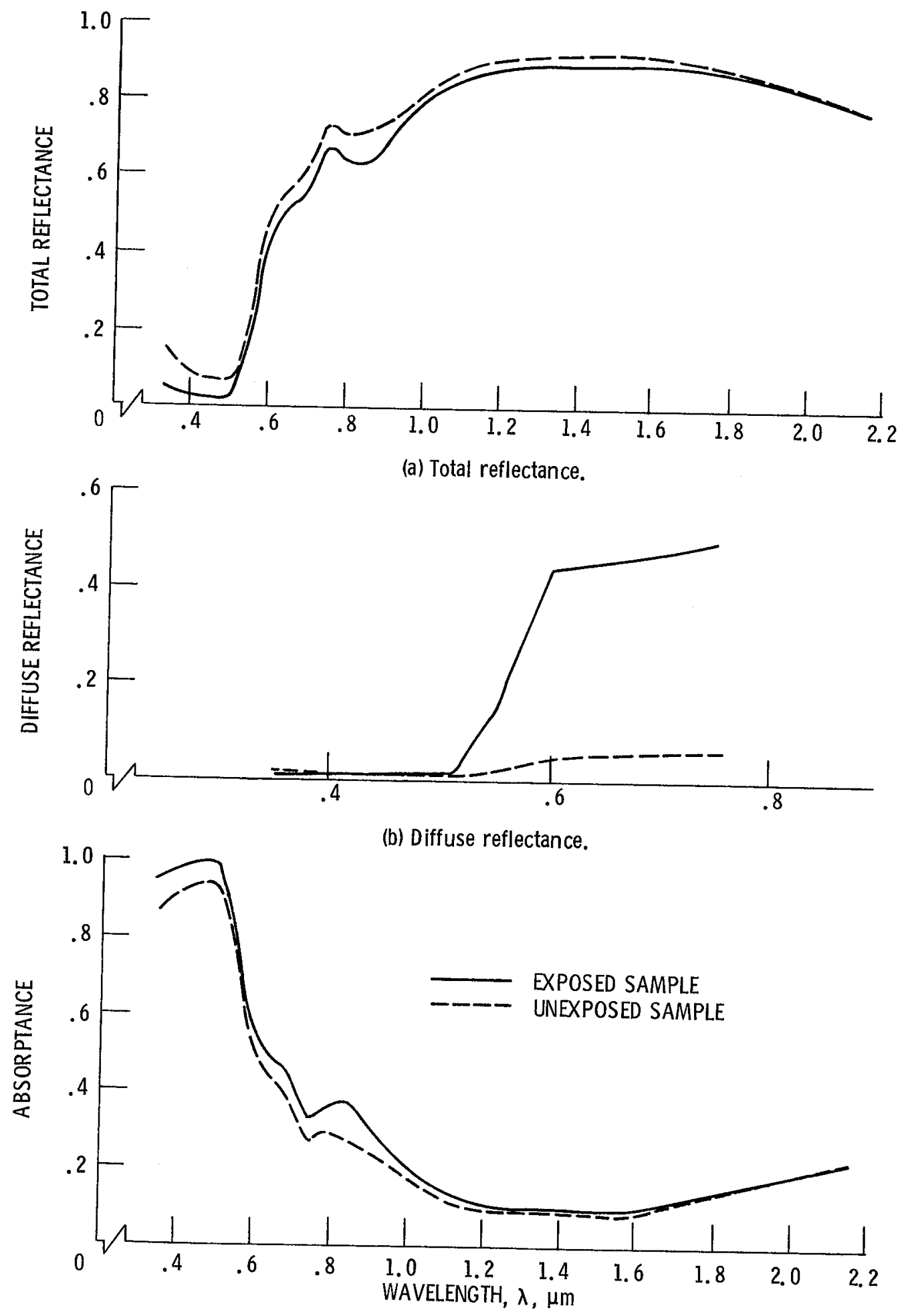

(c) Absorptance.

Figure 4. - Optical properties of unprotected Kapton® $10.127 \mathrm{~mm}$ thick with an aluminum film on the exposed surface) for samples unexposed and exposed to low earth orbital environment. 

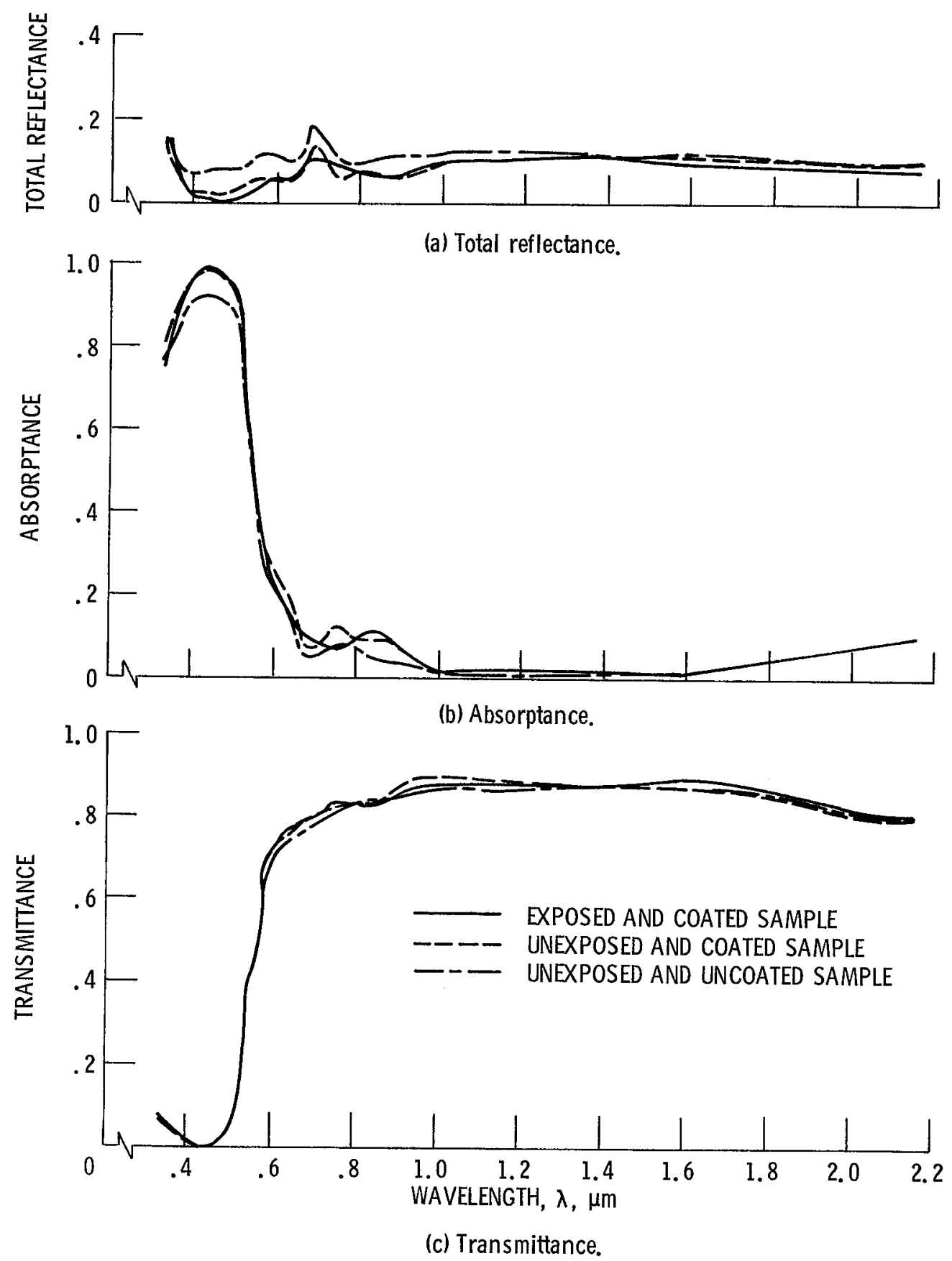

Figure 5. - Optical properties of $\geq 96 \% \mathrm{SiO}_{2} \leq 4 \%$ PTFE coated Kapton ${ }^{\circledR}$ samples unexposed and exposed to low earth orbital environment compared with uncoated and unexposed Kapton ${ }^{\circledR}$. 


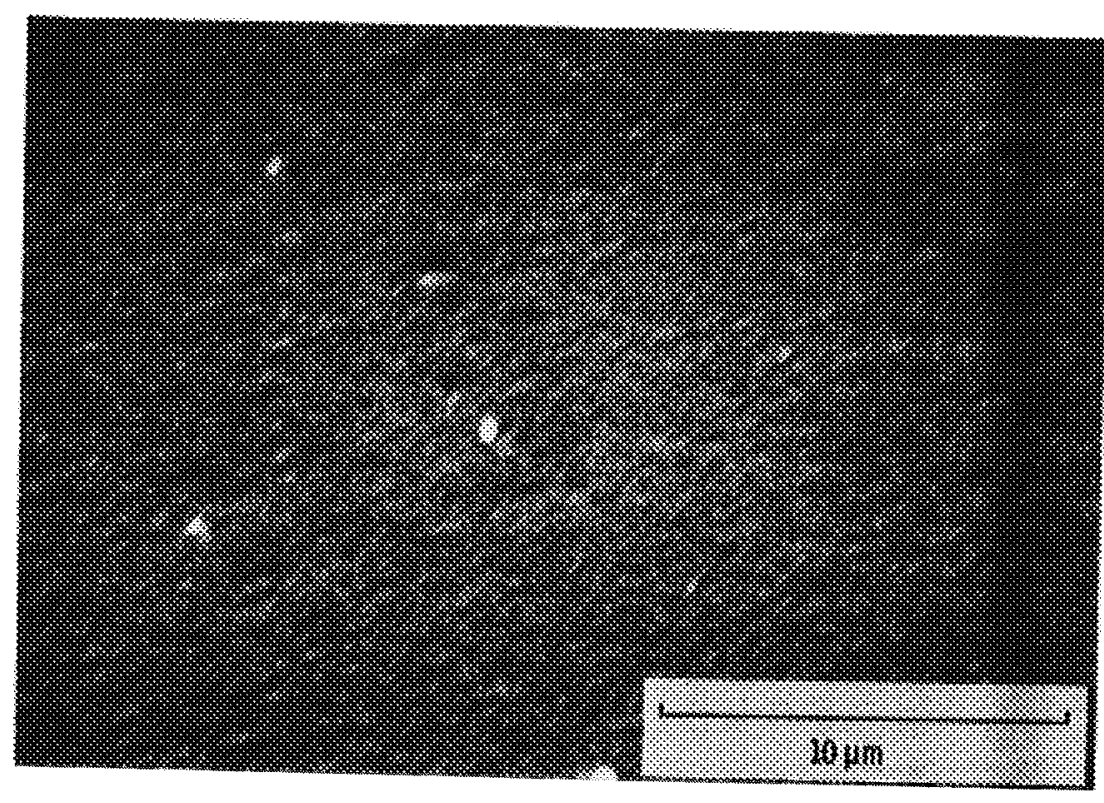

(a) Unprotected Kapton ${ }^{\circledR}$ before space exposure.

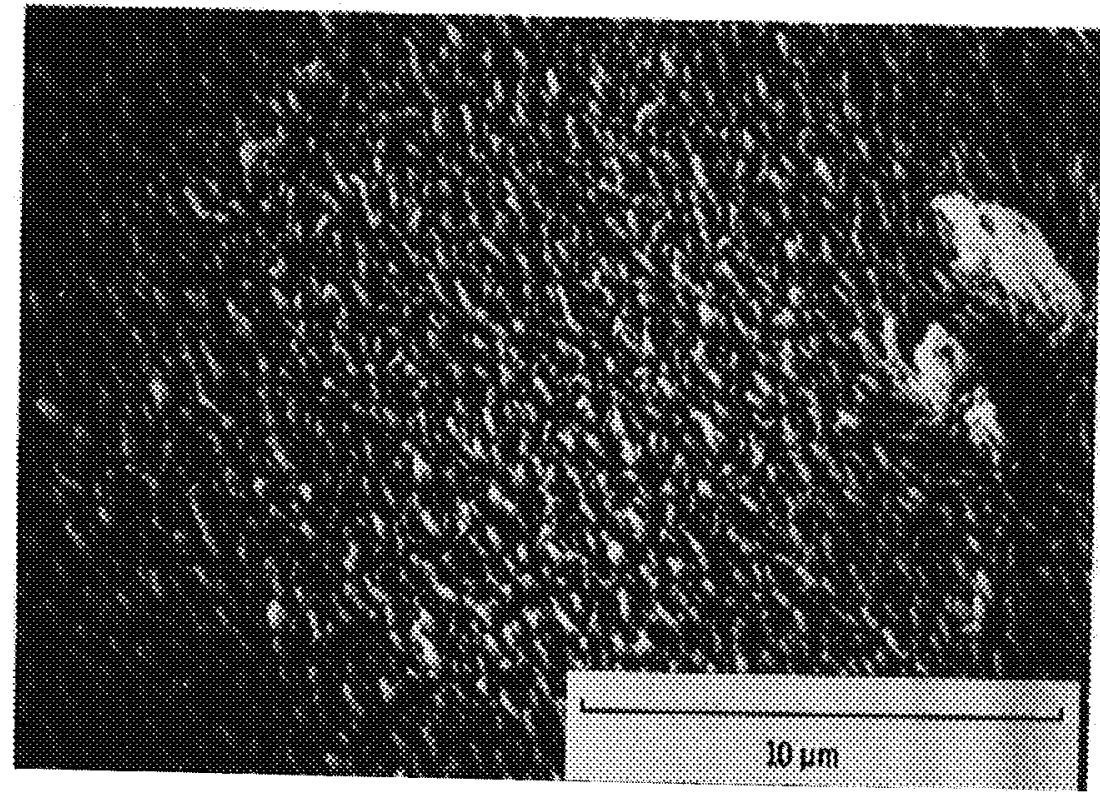

(b) Unprotected Kapton ${ }^{\circledR}$ after space exposure.

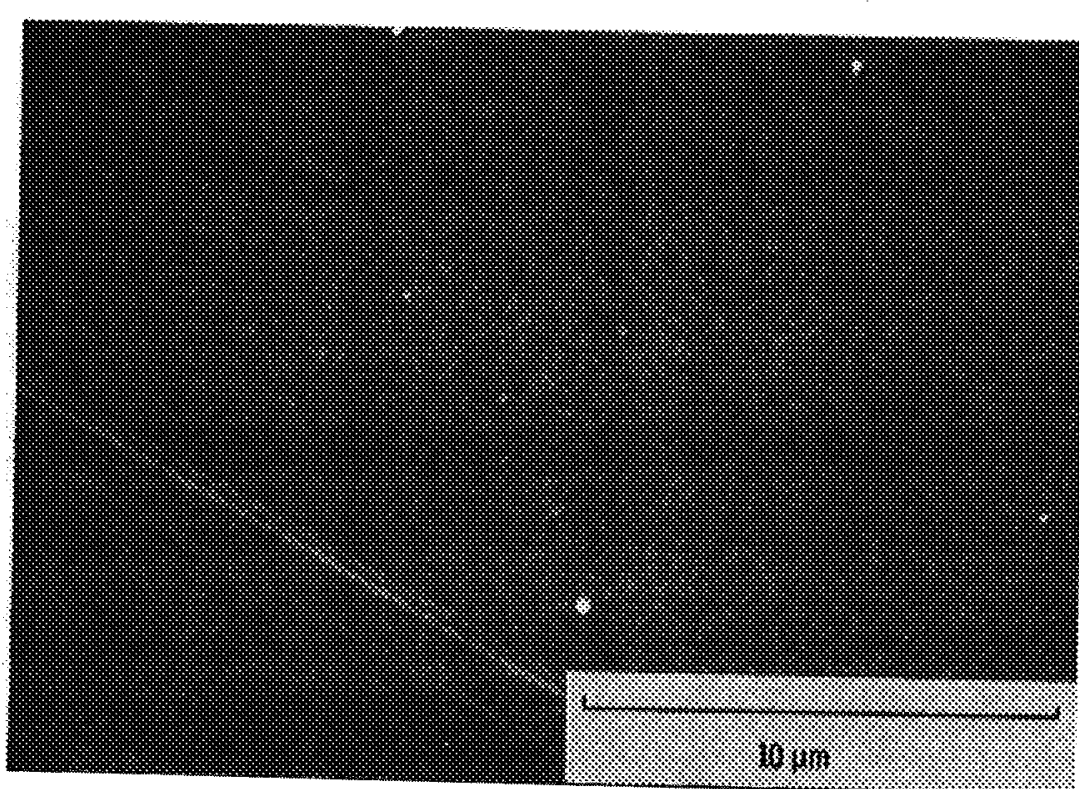

(c) $\geq 96 \% \mathrm{SiO}_{2} \leq 4 \%$ PTFE coated Kapton ${ }^{\circledR}$ before space exposure.

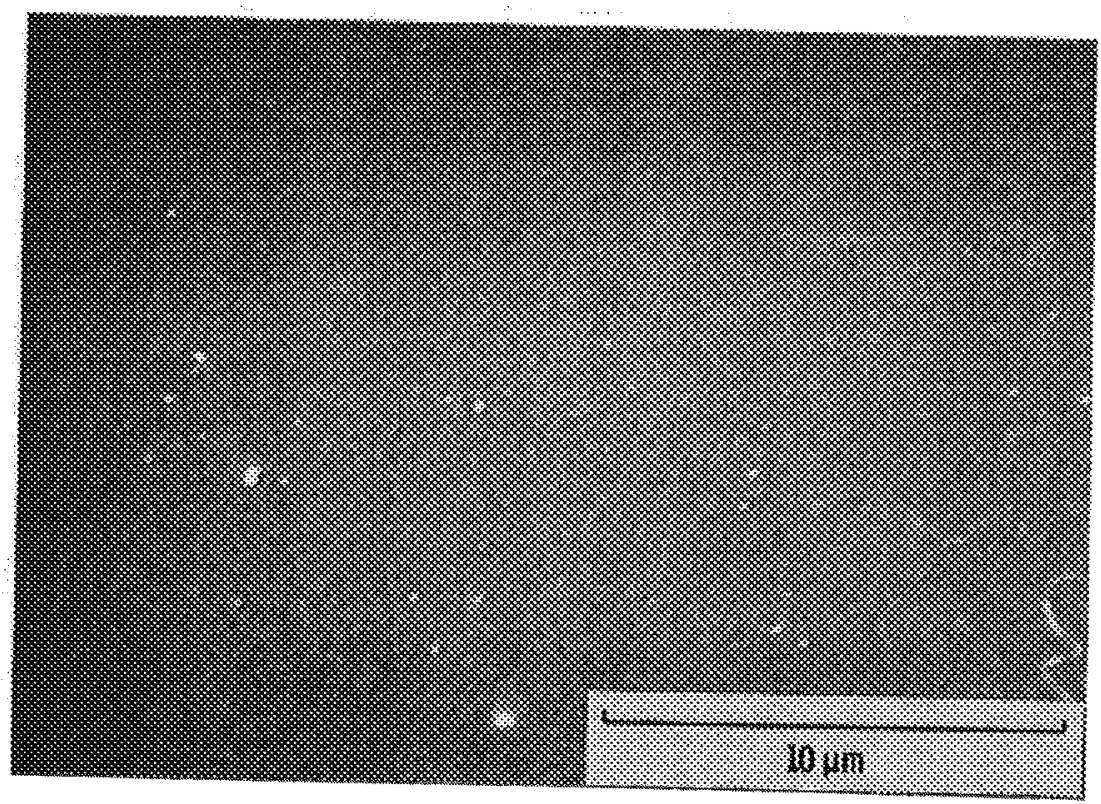

(d) $\geq 96 \% \mathrm{SiO}_{2} \leq 4 \%$ PTFE coated Kapton ${ }^{\circledR}$ after space exposure.

Figure 6. - Scanning electron microscope photographs of unprotected and $\geq 96 \% \mathrm{SiO}_{2} \leq 4 \%$ PTFE coated Kapton ${ }^{\circledR}$ before and after space flight exposure. 


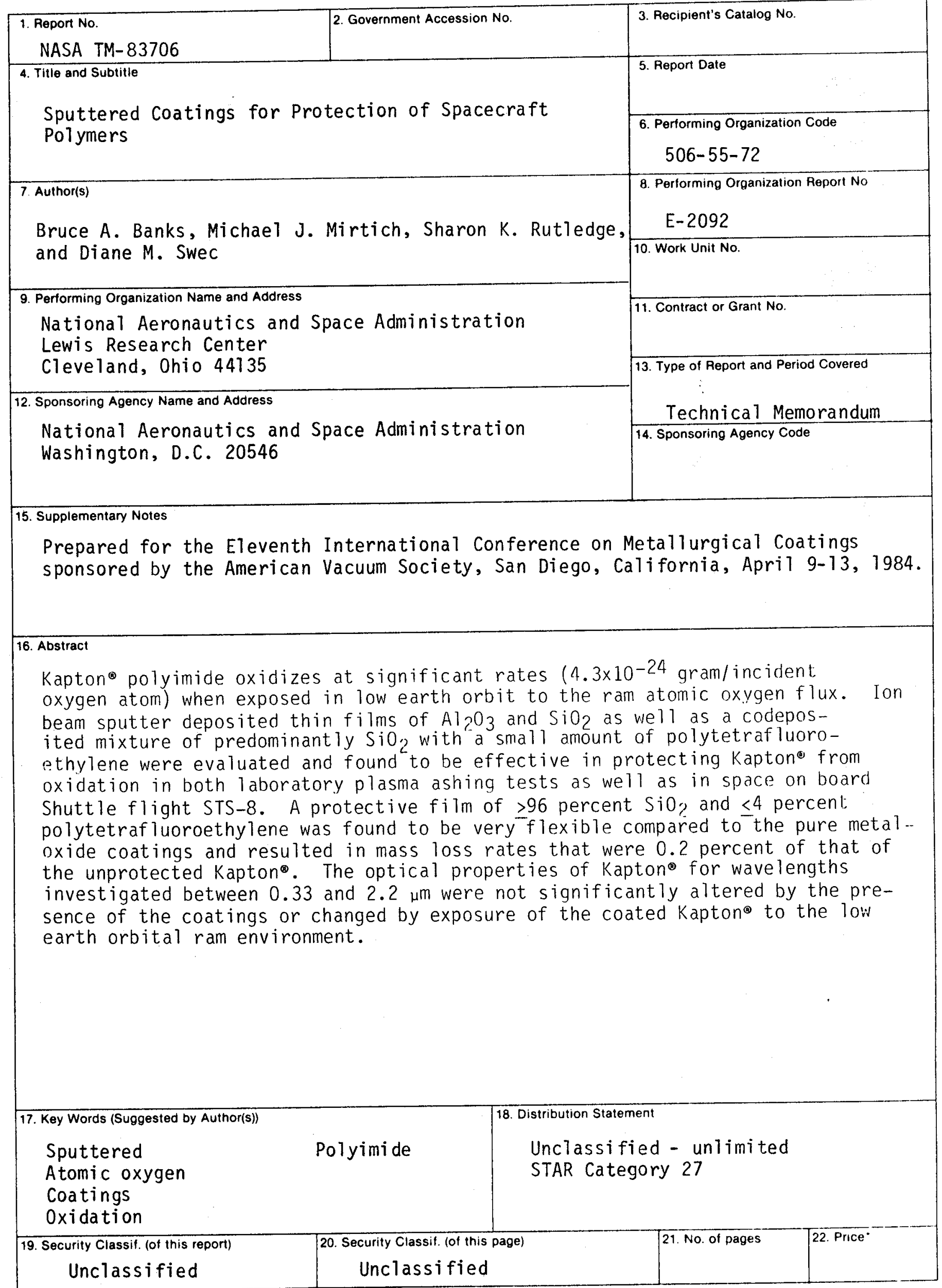

*For sale by the National Technical Information Service. Springfield, Virginia 22161 